\title{
Söyleși
}

\section{Erik SZAUDER ile Yaratıcı Drama Üzerine.}

\author{
Söyleşiyi yapan: Yrd. Doç. Dr. H. Ömer ADIGÜZEL \\ Çeviri: Tümay ÇOKLUK \\ "Drama anlaşılmazsa tiyatro ve eğitim de anlaşılmaz!".
}

\section{Erik Szauder yaratıcı drama'yı nasıl tanımlıyor?}

Bana göre yaratıcı drama diğer sanat dallarının bir parçası ve kökleri de tiyatroda ve eğitimde. İnanıyorum ki drama anlaşılmazsa tiyatro ve eğitim de anlaşılmaz. Yaratıcı drama farklı bir şeydir. Çünkü yaratıcı drama insanların bildikleri şeyleri içeriksel bir açıdan görmelerini sağlar.

\section{Yaratıcı drama eğitimdeki tıkanıklı̆̆a bir çözüm olarak görülebilir mi?}

Her şeyden önce, bu cevap vermesi zor bir soru. Buna cevap verebilmek için dramanın Türkiye'de ne anlama geldiğinin karmaşık bir betimlemesini yapmam gerekir. Ancak evet, dramayı eğitimde bir çözüm olarak görebiliriz. Ancak dramayı eğitimde son çare olarak görürsek yanlış yaparız. Eğitimde yaratıcı dramayı kullanmanın daha iyi bir hayat arayışı için bir yol olduğuna inanıyorum. Seminer haftası boyunca ve seminerin son günündeki gösterimizde spiral bir imge yapmaya çalıştım ve insanların anlayışlarını genişleten bir süreç düşündüm. Eğitimde dramanın son nokta olduğunu düşünürsek bu su spirali durdururuz. Eğitimde dramaya inanmama rağmen bunun son çare olduğunu söyleyemem ancak darama birçok yeyin olumlu yönde gelişmesine yardımcı olabilir.

\section{Macaristan'da eğitimde yaratıcı drama nasıl algılanıyor?}

Özelikle İngiltere ve Macaristan'da dramanın çok saygın bir alan olduğunu biliyorum. Bu ülkelerde 1960'larda ve 1970'lerde yaratıcı dramanın keşfedici bir aktivite olduğu görüldü. Bu yıllarda insanların kendi hayatları hakkında düşünme ve bir şeyler yaratma zorunluluğu varmış gibi hissedildi. İngiltere'de özellikle 1980'lerde ve 1990'larda ortaya çıkan tutucu ideolojiler nedeniyle yaratıcı drama okullarda daha az yer tutmaya başladı. Macaristan'da komik olan şey bu durumun temelde İngiltere'dekiyle aynı oluşuydu. 1980'lerin başında Macaristan'da drama sosyal ve bireysel bir aktivite olarak görüldü; gerçekte de öyleydi. Bireycilik de komünist ideolojiye karşıydı. Ancak değişimler olunca Macaristan demokratik ancak ekonomik bağlamda çok da iyi durumda olmayan bir ülke haline geldi. Eğitimde çok az para kaynağı varsa -ki Macaristan bu durumdaydı- genelde para yanlısı bir ideolojiyi benimser ve 
sonuçlara çabuk oluşmak istersiniz. İlk ve orta dereceli okullarda ve üniversitelerin eğitim programlarında yaratıcı drama adıyla dersler bulunmaktadır. Sonuç olarak elimizden geleni yapmaya çalışıyoruz.

\section{Ankara'daki semineri nasıl değerlendiriyorsunuz?}

Öncelikle burada olmaktan onur duyduğumu söylemek istiyorum. Çok iyi insanlar tanıdım ve hepsinin de bir şeyler öğrenme isteği vardı. Öğretmekle her zaman bir şeyler öğrendim. Bu hafta boyunca benim amacım Türklerin kendi geçmişlerini nasıl algıladıklarını onlara göstermekti. Türklerin kendilerini nasıl gördüğüne dair çok şey öğrendim. İnsanların kendilerini anlamaya yönelik bir sürece nasıl girdiklerini gördüm. Bu süreçte insanların çok şey öğrendiğine inanıyorum ancak kendilerini bir "joker” olarak gördüklerini söyleyemem. Ben bu süreçten ok hoşlandım. Umarım katılımcılar da aynı şeyi düşünüyordur. Yapılan yorumlar böyle olduğunu gösteriyor ancak bu hafta boyunca neyin nasıl öğretilmiş olduğunu hem benim hem de katılımcıların tam olarak anlaması biraz zaman alacaktır. Dramanın Türkiye'deki gelişimi bu haftadan sonra yorumlamaya çalışmak çok anlamsız olur. Gençlerle de çalıştım, deneyimli insanlarla da çalıştım. Yirmi yaşında, yani bir yolculuğun henüz başında olan insanlarla da, hayatın ikinci kısmını yaşayan insanlarla da beraberdim. Çalıştığım grubun farklı kavrayış düzeylerine sahip insanlardan oluştuğu kesin. Ancak söylediğim gibi, bu Türkiye'de dramayı özetleyici bir yorum olamaz. 